\title{
Influence of Emotional Intelligence and Gender on Job Satisfaction among Local Government Employees
}

\author{
Ngozi Sydney-Agbor ${ }^{1}$, Richards E. Ebeh ${ }^{1}$, Barnabas E. Nwankwo ${ }^{2, *}$, Solomon A. Agu ${ }^{3}$ \\ ${ }^{1}$ Department of Psychology, Imo State University, Owerri \\ ${ }^{2}$ Department of Psychology, Caritas University, Enugu \\ ${ }^{3}$ Department of Psychology, Enugu State University of Science and Technology, Enugu \\ *Corresponding author: banniewankwo@yahoo.com
}

Received November 25, 2014; Revised December 05, 2014; Accepted December 15, 2014

\begin{abstract}
The study examined the influence of emotional intelligence and gender on job satisfaction among employees of Owerri Municipal and Oguta Local Government Councils, in Imo State, South East Nigeria. One hundred and sixty fulltime employees of the councils with ages ranging from $25-52$ years and a mean age of 37.5 were drawn through accidental sampling. Two standardized instruments were used in this study; the Emotional Intelligence Questionnaire by Schutte et al. (1998) and the Minnesota Satisfaction Inventory by Weiss, Dawis, England and Lofquist (1967). A cross-sectional survey design was adopted while a 2-Way Analysis of Variance on SPSS version 17 was used for data analysis. Results showed that emotional intelligence had a significant influence on job satisfaction, with high emotionally intelligent employees showing more satisfaction. The result however showed that gender had no significant influence on job satisfaction. Also, no interaction effect was found between the variables. The results were discussed in line with current studies on emotional intelligence, gender and job satisfaction.
\end{abstract}

\section{Keywords: job satisfaction, emotional intelligence, gender, Local Government Employees}

Cite This Article: Ngozi Sydney-Agbor, Richards E. Ebeh, Barnabas E. Nwankwo, and Solomon A. Agu, "Influence of Emotional Intelligence and Gender on Job Satisfaction among Local Government Employees." Research in Psychology and Behavioral Sciences, vol. 2, no. 4 (2014): 86-89. doi: 10.12691/rpbs-2-4-2.

\section{Introduction}

Job satisfaction refers to a collection of attitudes, which workers have about their jobIt describes how content an individual is with his or her job and it has been defined in many ways. Hulim and Judge (2003) saw it as multidimensional psychological responses to an individual's job which has cognitive, affective and behavioural components. There are variety of factors that can influence a person's level of job satisfaction; some of these factors include the level of pay and benefits, the perceived fairness of the promotion system within a company, the quality of the working condition, leadership and social relationship and the job itself (the variety of tasks involved, the interest and challenge the job generates and the clarity of the job description requirement). Other variables that may influence job satisfaction are dispositional variables such as personality, emotional intelligence, gender etc.

The happier people are with their job, the more satisfied they are said to be. Various steps are taken by organizations to improve and enhance job satisfaction; these include job rotation, job enlargement and job enrichment. Indeed, reaching to optimum productivity is the most considerable aim of each organization. Undoubtedly, proficient, happy and skilful human force is one of the most important elements that help organizations to achieve their goals, because human force plays a significant role in changing the level of productivity. Abraham (1999) claimed that emotionally intelligent individuals are more skilled to cope with life activities and they have productive thinking which often includes affective awareness.

Initially, Mayer and Salovey presented the concept of emotional intelligence which is the subset of social intelligence that involves the ability to monitor one's own and other's feeling and emotions, to discriminate among them and to use this information to guide one's thinking and action (Mayer \& Salovey, 1993). Mayer and Salovey (1993) asserted that emotional intelligence is not just positive characteristic; rather it consists of logical and emotionally diverse ability with social intelligence. It considers vital emotional issues as well as appeasing both personal and social difficulties. Individuals who are more emotionally intelligent have more life satisfaction, partake in others emotion, and also usually are more ordered, warm, prosperous, and optimistic (Salaski \& Gartwright, 2002).

Emotional intelligence has its link to Thorndike's (1920) concept of Social intelligence which he defined as the ability to understand and manage men and women, boys and girls-to act wisely in human relations. The term became popular by Daniel Goleman with the publication of his book "why it can matter more than 1Q" in the early 
1990. Goleman (1998) introduced his emotional intelligence based on performance theory (that is merit based) including a separable set of abilities that integrate cognitive and effective skills. Selecting employees based on high level of emotional intelligence would enable organizations to profit in multiple ways. According to Wong and Song (2004), a lack of emotional intelligence in employees could negatively affect their satisfaction and commitment which could reveal itself in familiar symptomatic ways, comprising burnout, turnover, poor attitudes, shoddy performance, and stressed relationships.

Referring to Goleman (1998), emotional intelligence has five major components: self-awareness, self-regulation, motivation, empathy and social skills. Self-awareness refers to the ability of a person to perceive his strengths, emotions, worth and capabilities. Self-regulation is often seen as the ability of a person to control emotional automatic interactions and think before implementing behaviour. Motivation is sometime related to the internal force that drives to enable a person to focus on the task on hand and continue to reach his goals. Empathy is viewed as the power of a person to perceive the other's feelings and this may help them to act on those feelings and meet other's needs. Social skills are needed to develop and create good working relationships.

In the context of the emerging affective revolution in social and organizational psychology (Barsade \& Gibson, 2007), emotional intelligence (EI) is proposed as an important predictor of key organizational outcomes including job satisfaction (Daus \& Ashkanasy, 2005); (Van Rooy \& Viswesvaran, 2004). There is cumulating evidence that EI abilities and traits influence job satisfaction (Carmeli, Yitzhak - Halevy \& Weishberg; 2009; Sy, Tram \& Hara 2006).

There is accumulating evidence that emotional intelligence abilities and gender influence job satisfaction (Carmeli et al., 2009; Sy et al., 2006). Afolabi, Awosola and Omole, (2010) examined the influence of emotional intelligence and gender on job performance and satisfaction among Nigeria Police Officers. They found that police officers who are high on emotional intelligence are more satisfied and perform better than police officers who are of low emotional intelligence.

Barsade and Gibson (2007) proposed that emotional intelligence is an important predicator of key organizational outcomes including job satisfaction. Furthermore, there is evidence that emotional intelligence is related to job satisfaction in Chinese's sample (Wong, Wong \& Law, 2007).

Emotion regulation had unique predictive power for affect and job satisfaction for the younger age group (Kafetsios \& Loumakou, 2007) when survey was conducted on 475 educators in Greek. Carmeli (2003) and Schutte et al. (1998) found a positive relationship between emotional intelligence and work attitude.

Numerous researches have also observed a relationship between trait emotional intelligence measures and job satisfaction (Carmeli et al., 2009; Kafetsions \& Loumaku, 2007, Vacola, Tsaousis \& Nikolaou, 2003). Research also suggests that people with high level of emotional intelligence lead more effectively (Dimitriades, 2007); are efficient job performers (Carmeli, 2003) engage in organizational citizenship behaviour (Carmeli, 2003); Feel satisfied with their job, and committed both to their career and to their employing organization (Carmeli, 2003).

Patra (2004) in his research on the relationship between emotional intelligence and job satisfaction proved that those employees who are emotionally intelligent find their place of work satisfying and this influence their satisfaction and overall productivity that lead to efficient management and organizational development.

In another study on the impact of emotional intelligence and gender on job satisfaction among Egyptian government sector employees, Ghoniem, Elkhouly, Mohsen and Ibrahim (2011) found that employees who are of high emotional intelligence are more satisfied with their work than the employees who are of low emotional intelligence. The study also identified that gender has a insignificant influence on job satisfaction.

Hassan, Hashim and Ishak (2011) conducted a study on the relationship between demographics variables, emotional intelligence, communication effectiveness, motivation and job satisfaction. They found that emotional intelligence is one of the most vital factors that help sustain communication effectiveness and job satisfaction.

In another study, Thomas, Susana and Linda (2006) examined the relationships between employee's emotional intelligence, their manager's emotional intelligence and job satisfaction and performance among 187 food attendants from nine different locations of the same restaurant franchise. They found that employees' emotional intelligence was positively associated with job satisfaction and performance. In addition, manager's emotional intelligence has a more positive correlation with job satisfaction for employees' with low emotional intelligence than for those with high emotional intelligence. Similarly, Sy, Tram and Hara (2006) found that manager's emotional intelligence had a more positive correlation with job satisfaction for employees with low emotional intelligence than for those with high emotional intelligence.

In a study of Israeli secondary school teachers, KremerHayon and Goldstem (1990) reported that women teachers experience more job satisfaction than was the case with men. Similarly, in a study of stress and job satisfaction among 844 primary school teachers in Malta, Borg and Falzon (1989) observed that women teachers showed greater satisfaction with teaching than men. Similarly, Xin and Macmillan (1999) found that female teachers appear to be more satisfied with their professional role than male colleagues. This study was conducted in Canada on the influence of work place condition on job satisfaction.

Generally, empirical evidences on the influence of emotional intelligence and gender on job satisfaction is sparse in Nigerian and especially among Local Government employees. This study therefore seeks to close this gap by identifying if differences in emotional intelligence and gender will influence local government workers job satisfaction. To achieve this goal, the following hypotheses were tested:

i. High and low emotionally intelligent workers will not differ in their job satisfaction

ii. Male and female workers will not differ in their job satisfaction.

iii. Emotional intelligence and gender will have no interaction effect on job satisfaction. 


\section{Method}

\subsection{Participants}

A total of 160 fulltime employees of Owerri Municipal and Oguta Local Government Councils participated in this study. They were drawn through accidental sampling. The participants comprised of 85 females and 75 males. Their ages ranged between 25 - 50 years with a mean age of 37.5 years. All participants had a minimum of Senior Secondary School education.

\subsection{Instruments}

Two instruments were employed in this study; the Emotional Intelligence Questionnaire and the Minnesota Satisfaction Inventory. The Emotional Intelligence Questionnaire was developed by Schutte et al. (1998). It is a 33 - item scale structured in a 5-point Likert format from Strongly Disagree (1) to Strongly Agree (5). The emotional intelligence scale was revalidated by the researcher and a Cronbach alpha reliability of .92 was obtained. The norm for the scale is 70.2. Scores above the norm indicates low emotional intelligence, and vice versa. The Minnesota Satisfaction Inventory (a measure of job satisfaction) was developed by Weiss, Dawis, England and Lofquist (1967). The scale consists of 20 items which requires the respondents to indicate how satisfied they are with their job by rating each item on a 5-point Likert format from Very Dissatisfied (1) to Very Satisfied. Weiss et al (1967) reported a one week interval test retest reliability coefficient of .94 . Mogaji (1997) provided the Psychometric properties for the Nigerian sample. The norm for the scale (Nigerian sample) is 65.13; score higher than the norm indicates adequate job satisfaction. Also demographic details such as gender, age, educational level and marital status were included in the instruments used for the study.

\subsection{Procedure}

A total of 210 questionnaires were distributed to participants approached at their offices in the two selected councils and who were willing to respond to the questionnaire. The participants were given two days to respond to the scale after which the researchers retrieved them. Out of the 210 copies distributed, 160 copies were returned, completely filled and were used for the study. This represents $76.19 \%$ response rate. The participants demographic variables are presented below.

Table 1. Demographic variables of participants

\begin{tabular}{|lll|}
\hline Variables & Frequency & Percentage $(\%)$ \\
Female & 85 & 53.13 \\
Male & 75 & 46.88 \\
Married & 89 & 55.63 \\
Single & 71 & 44.38 \\
$25-35 y r s$ & 58 & 36.25 \\
$36-45 y r s$ & 64 & 40 \\
$46+$ & 38 & 23.75 \\
\hline
\end{tabular}

\subsection{Design \& Statistic}

The Cross-Sectional Survey Design was adopted for the study while data was analyzed using f-test for 2-Way ANOVA.

\section{Results}

Table 2. Summary of Means and Standard Deviations for Emotional Intelligence and Gender on Job Satisfaction

\begin{tabular}{llll} 
Intelligence and Gender on Job Satisfaction & & \\
\hline Variables & Mean & Standard Deviation & $\mathrm{N}$ \\
\hline High Emotional Intelligence & 70.52 & 12.69 & 56 \\
Low Emotional Intelligence & 65.27 & 9.42 & 104 \\
Female & 66.52 & 10.93 & 85 \\
Male & 67.77 & 10.97 & 75 \\
\hline
\end{tabular}

Table 3. Summary Table of Two-Way ANOVA for Emotional Intelligence and Gender on Job Satisfaction

\begin{tabular}{llllll}
\hline Source & Type III Sum of Squares & df & Mean Square & F & Sig. \\
\hline Emotional Intelligence (A) & 902.92 & 1 & 902.92 & 8.03 & $.01^{\text {Sig }}$ \\
Gender (B) & 27.02 & 1 & 27.02 & .24 \\
A X B & 317.77 & 1 & $317.77^{\text {NS }}$ & 2.83 \\
\hline
\end{tabular}

Sig = Significant, ${ }^{\text {NS }}=$ Not significant

Based on the result of the f-test presented in Table 2, the first hypothesis was rejected, $F(1,156)=8.03, p=.01)$. Workers who are high in emotional intelligence $(\mathrm{M}=$ 70.52 , SD $=12.69$ ) were satisfied with their jobs more than their counterparts of low emotional intelligence $(\mathrm{M}=$ $65.27, \mathrm{SD}=9.42$ ). Thus emotional intelligence influences job satisfaction.

However, the second hypothesis is upheld, $F(1,156)$ $=.24, p=.63$ implying that males and females do not significantly vary in their levels of job satisfaction. Similarly, no significant interaction effect $F(1,156)=2.83$, $p=.10$ was found in job satisfaction between emotional intelligence and gender.

\section{Discussion}

The result of this study extends previous research on emotional intelligence and gender on job satisfaction. The study also examines the joint influence of these variables in enhancing job satisfaction. The first hypothesis which predicted that there will be no statistical significant influence of emotional intelligence on job satisfaction does not receive support. The result of this analysis shows that employees who are of high emotional intelligence were satisfied with their job than employees who are of low emotional intelligence. The result is in consonance with the findings of Tans (2003) whose study found a positive relationship between emotional intelligence and several other criteria such as job satisfaction and performance. This result is also in line with Afolabi et al. (2010) and Sy et al. (2006) who found that employees' emotional intelligence was positively associated with job satisfaction. It is assumed that individuals with high emotional intelligence may use buffering techniques to internally encapsulate and segregate emotions so that it does not interfere with their job thereby enhancing their job satisfaction. The second hypothesis which predicted that there will be no statistical significant influence of gender on job satisfaction was supported. The result 
shows that males and females did not vary significantly in their levels of job satisfaction. The result confirms the findings of Ghoniem et al. (2011) who found insignificance influence of gender on job satisfaction. This result is also in line with Sauser and York (1978); Hulin and Smith (1964) findings that gender is not a relevant determinant of either high or low job satisfaction. However, when gender is matched with separate factors like the pay, job level and promotional possibility, they may influence job satisfaction.

This finding contradicts the findings of Kremer-Hayon and Goldstem (1990), Malta, Borg and Falzon (1989) and Xim and Macmillan (1999) who found significant influence of gender on job satisfaction. The third hypothesis which predicted that emotional intelligence and gender will not interact to influence job satisfaction received support. This finding contradicts the findings of Hartley (2009) who asserts, that emotional intelligence can work with other variables like gender, personality and personal value to predict job satisfaction.

Based on the finding of this research, further studies were suggested, namely;

- The relationship between age and emotional intelligence as well as the mediating role of age on the relationship between EI and job satisfaction.

- Roles of Marital status on emotional intelligence and job satisfaction.

\section{Conclusion}

The finding of this study has revealed the need for employers of labour to consider emotional intelligence alongside other requirements needed during employee selection. The more employees are high in emotional intelligence, the more they are satisfied with their job which will in turn lead to better service quality. Since emotional EI can be learned according to learning theories, employees should learn to control their emotions and be sensitive to that of others. This can be facilitated if management can provide training programs aimed at educating and improving workers emotional intelligence. Another important discovery of this study is that job satisfaction is not determined by gender. Based on this, females should not be discriminated against during employment. To ensure a satisfied work force with high emotional intelligence, the organizational climate should be conducive physically and psychologically.

\section{References}

[1] Abraham, R. (1999). Emotional intelligence in organizations: A conceptualization. Genetic, Social, and General psychology monographs, 125, 209-227.

[2] Afolabi, A.O., Awosola, R.K. \& Omole, S.O. (2010), Influence of emotional intelligence and gender on job performance and satisfaction among Nigerian policemen. Journal of Social Science 2(3), 147-154.

[3] Barsade, S., \& Gibson, D. (2007). Why does affect matter in organization? Acad. Manage Perspect, 21(1), 36-57.

[4] Hulim, C.L., \& Judge, T.A. (2003). Job attitudes. In W.C. Borman, D.R. Ligen, \& R.J. Klimoski (Eds.), Handbook of Psychology: Industry and Organizational Psychology, pp. 255-276. Hoboken, NJ: Wiley.
[5] Borg, M. G. \& Falson, J.M. (1989). Primary school teachers' perceptions of pupils' undesirable behaviours. Educational Studies $15,251-260$.

[6] Carmeli, A. (2003). The relationship between emotional intelligence and work attitudes, behaviour and outcomes: An examination among senior managers: Journal of Managerial Psychology. 18(8), 758-813.

[7] Carmeli, A., Yitzhak - Halevy, M. \& Weishberg, (2009). The relationship between emotional intelligence and psychological wellbeing. Journal of Managerial Psychology 24(4), 66-78.

[8] Daus, C. S. \& Ashkanasy, N. M. (2005). The case for the abilitybased model of emotional intelligence in organizational behavior. Journal of Organizational Behavior, 26, 453-466.

[9] Dimitriades, Z.S. (2007). Managing emotionally intelligence service workers; personal and positional effects in Greek context. Journal of European Industrial Training 31(3), 223-240.

[10] Ghoniem, A., Elkhouly, S., Mohsen, G. \& Ibrahim, M. (2011). Impact of Emotional intelligence and gender on job satisfaction among Egyptians government sector employees. Current research Journal of Social Sciences 3(1), 22-27.

[11] Goleman, D. (1995). Emotional Intelligence. New York: Bantam Books.

[12] Goleman, D. (1998). What makes a leader: Harvard Business Review, 76(6), 93-102.

[13] Hassen, J., Hashim F.B.Y \& Ishak M.S. (2011). The relationship between demographics variables, emotional intelligence, communication effectiveness motivation and job satisfaction. International Journal of Academic Research in Business and Social Sciences. 1(1), 35.52.

[14] Iiafetsios, K. \& Loumakou, M. (2007). A comparative evaluation of the effects of trait emotional intelligence and emotional regulation on affect at work and job satisfaction. International Journal of Work Organization Emotion, 2(1), 71-87.

[15] Law, K.S., Wong C.S., \& Song, L.J. (2004). The construct and criterion validity of emotional intelligence and its potential utility for management studies. Journal of Applied Psychology, 89, 483496.

[16] Mayer, J.D., \& Salovey, P. (1993). The intelligence of emotional intelligence. Intelligence, 17, 433-442.

[17] Mogaji, A.A. (1997). The effect of organizational climate on employee commitment, involvement and motivation from Nigerian manufacturing industry. Unpublished Ph.D Thesis, University of Lagos.

[18] Patra, S. (2004). Role of emotional intelligence on educational management Journal of Indian Education, 30(1), 98-104.

[19] Salaski, M., Gartwright, S. (2002). Health, performance and emotional intelligence: an exploratory study of retail managers, 8 , 63 68. Retrieved from http:// www.interscience.Wiley.com.

[20] Schutte, N.S., Malouff, J.M. Hall, L.E. Haggerty, D.J., Cooper, J.T., Golden, C.J. \& Dornhesim, L. (1998). Development and validation of a measure of emotional intelligence. Personality and Individual Differences, 25, 167-77.

[21] Sy, T., Tram. S. \& O’Hara, L., (2006). Relation of employee and manager to job satisfaction and performance: Journal of Vocational Behaviour, 68(3), 461-443.

[22] Thomas, S., Sussana, T. \& Linda A.O. (2006). Relation of employee and manager emotional intelligence to job satisfaction and performance. Journal of vocational behaviour 68(3), 461-473.

[23] Thorndike, E.L. (1920). Intelligence and its uses. Harper's Magazine, 140, 227-235.

[24] Vacola, M. Tsaousis, I. \& Nikolaou, I. (2003). The role of Emotional intelligene and personality variables on attitudes toward organizational change. Journal of Managerial Psychology, 19(2), 88-10.

[25] Van Rooy, D.L. \& Viswesvaran, (2004). Emotional intelligence: A meta-analytic investigation of predicative validity and nomological net. Journal Vocation Behaviour, 65, 71-95.

[26] Weiss, D.J., Dawis, R.V. England, G. W. and Lofquist, L. H. (1967), Manual for the Minnesota Satisfaction Questionnaire. Vol 22, Minnesota Studies in Vocational Rehabilitation, Minneapolis: University of Minnesota, Industrial Relations Center.

[27] Wong, C.S., Wong P.M. \& Law, K.S. (2007), Evidence on the practical utility of Wong's emotional intelligence scale in Hong Kong and Mainland China. Asia Pacific Journal of Management 24(1), 43-60.

[28] Xin, M.\& MacMillan, R. (1999). Influences of workplace conditions on teachers' job Satisfaction. Journal of Educational Research, 93(1), 39-47. 